\title{
WAITING FOR THE END IN BIAK: VIOLENCE, ORDER, AND A FLAG RAISING ${ }^{1}$
}

\section{Danilyn Rutherford}

\section{A "Not Wholly Peaceful" Protest}

On July 6, 1998, just before dawn, soldiers opened fire on a group of some two hundred demonstrators, in Biak City, on Biak Island, in Biak-Numfor Regency, in the Indonesian province of Irian Jaya. ${ }^{2}$ For four days, the demonstrators had been guarding

\footnotetext{
${ }^{1}$ This essay is based on research supported by a US Department of Education Fulbright-Hays Doctoral Dissertation Research Abroad Fellowship, a Predoctoral Grant from the Wenner-Gren Foundation for Anthropological Research, a grant from the Joint Committee on Southeast Asia of the Social Science Research Council and the American Council of Learned Societies with funds provided by the Andrew W. Mellon Foundation, the Ford Foundation, and the Henry Luce Foundation, and a grant from the J. David Greenstone Memorial Fund of the University of Chicago Division of Social Sciences. A version of this essay was presented in a session entitled "Violence and the Political Economy of Terror in Irian Jaya" at the Annual Meeting of the American Anthropological Association, Philadelphia, PA, December 3, 1998. I would like to thank Stuart Kirsch for organizing this panel. I would also like to thank Benedict Anderson, Deborah Homsher, Rupert Stasch, and Mary Steedly for their helpful comments and criticisms. Any errors are, of course, my own.

${ }^{2}$ Advocacy organizations reporting on the internet about the flag raising include Human Rights Watch, "Indonesia Alert: Trouble in Irian Jaya," July 6, 1998, "Irian Jaya Detainees Denied Family Visits, Medical Care," July 9, 1998, "Indonesia: Human Rights and Pro-Independence Actions in Irian Jaya," December 1998; Survival International, "Urgent Action Needed: People Shot in Biak, West Papua/Irian," July 6, 1998, "Update from Biak," July 9, 1998; TAPOL, "Situation Tense in Biak," July 5, 1998; and Buset Foker LSM, "Perkembangan Kasus Irian Jaya," July 8, 1997. Internet press reports include (among many others) "Akibat Kurusuhan di Irja 16 Ditahan, 20 Dirawat," Suara Pembaruan, July 8, 1998; "Irian Tribes Defy Slaughter," Sydney Morning Herald, July 8, 1998; "Indonesia's Black Death," Sydney Morning Herald, November 11, 1998; "Indonesian Church Groups: Two Shot Dead in Irian Jaya," Inside China, July 10, 1998; "Activists Rally in Indonesian Region," Associated Press, July 4, 1998; "Focus: Indonesian Troops
} 
a flag that flew on top of a water tower between the regency's main market and the port. They had raised the flag before dawn on July 2 . Later that morning, at an open forum, their leader, a young civil servant named Philip Karma, read an oath of allegiance to West Papua, the name of the sovereign nation that Karma and others would like Irian Jaya to become. On behalf of the Papuan people, Karma vowed not to abandon the flag and urged Kofi Annan to come to Biak to hear their case. That afternoon, when the security forces attempted to break up the demonstration, the followers wounded several policemen and burned a military truck. On July 5, after negotiations with the demonstrators broke down, authorities issued an ultimatum. If the crowd did not lower the flag voluntarily, troops would remove it by force.

The shooting is said to have lasted from 5:30 to 7:00 a.m. Just how many people were injured and killed in the operation remains unclear. Colonel Edyono, the armed forces commander in Biak, initially announced that there were twenty-one casualties and no fatalities. ${ }^{3}$ Other sources have put the death toll between five and a hundred; reports of torture and disappearances abound. ${ }^{4}$ After the Indonesian Human Rights Commission investigated the incident, the military leader finally admitted that one man, Ruben Orboi, had been killed. ${ }^{5}$ Orboi's body had been carried out to the sea, the commander told reporters. Fearing further unrest, the soldiers had decided to conceal the death temporarily by hiding the corpse in a shallow, beachside grave. When I arrived in Biak in late July for a brief visit, bodies had begun washing up on Biak beaches. Although the government claimed to have proof that these corpses were victims of the tsunami that struck Papua New Guinea on July 18, the police ordered villagers to bury them immediately. ${ }^{6}$ When I left Biak in early August, Philip Karma remained in police custody, with gunshot wounds to both of his legs. ${ }^{7}$ It seems likely that the flag lowering cost many more than one of his supporters their lives.

The "Morning Star Flag," which the Biak demonstrators were guarding, was officially raised next to the Dutch flag on December 1, 1961, less than a year before the United States and Australia brokered the deal that decided the fate of Netherlands

Tackle Fresh Irian Rally," Reuters, July 7, 1998; "Indonesians Dismantle Irian Separatist Flag Pole," Reuters, July 8, 1998; and "Indonesian Activists Say Five Missing in Irian," Reuters, August 7, 1998.

${ }^{3}$ See "Irian Tribes Defy Slaughter," Sydney Morning Herald, July 8, 1998; "Focus: Indonesian Troops Tackle Fresh Irian Rally," Reuters, July 7, 1998; "Indonesians Dismantle Irian Separatist Flag Pole," Reuters, July 8, 1998; and "Indonesian Church Groups: Two Shot Dead in Irian Jaya," Inside China, July 10, 1998.

${ }^{4}$ See Human Rights Watch, "Irian Jaya Detainees Denied Family Visits, Medical Care," July 9 1998; Survival International, "Urgent Action Needed: People Shot in Biak, West Papua/Irian," July 6, 1998 and "Update from Biak," July 9, 1998. According to Human Rights Watch, the military attack resulted in three confirmed fatalities. Ruben Orboi, discussed below, died on the scene, and two more of Karma's supporters died shortly after the military released them from detention. To date, ten others have been reported missing. See "Indonesia: Human Rights and Pro-independence Actions in Irian Jaya."

${ }^{5}$ See Cendrawasih Pos, July 25, 1998: 1, 4.

6 See "Lagi Sembilan Mayat Ditemukan di Biak Timur," Cendrawasih Pos, July 29, 1998: 1; "Masih Dalam Penyelidikan," Cendrawasih Pos, July 29, 1998: 1; “Korban Tsunami PNG di Biak Ditemukan Mencapai 28 Orang," Cendrawasih Pos, August 1, 1998: 1; and "Fishermen Find Bodies Off Indonesian Coast," Guardian Weekly, August 9, 1998: 4; see also Human Rights Watch, "Indonesia: Human Rights and Pro-Independence Actions in Irian Jaya."

${ }^{7}$ Convicted of rebellion for his role in the flag raising, Karma was sentenced to six and a half years in prison in January of this year. See "Irian Jaya Man Jailed Over Separatist Protest," AFP, January 31, 1999. 
New Guinea. ${ }^{8}$ In 1949, when the rest of the Indies gained independence, the Netherlands had retained the western half of the island of New Guinea, arguing that it was preparing its "primitive" Papuans for self-rule. In 1962, facing high deficits, heavy U.S. pressure, and the threat of war, the Dutch agreed to relinquish the territory to Indonesia. A United Nations Temporary Executive Authority (UNTEA) was established to oversee the transfer and to assist in preparations for an "Act of Free Choice" in which western New Guinea's inhabitants would have a chance to choose between remaining within Indonesia or founding an independent West Papuan state. It soon became clear that Indonesia would not honor the principle of "one man, one vote" in the plebiscite, which was scheduled for $1969 .{ }^{9}$ Headed by Ali Moertopo, a Special Operation for West Irian led the campaign for integration, often resorting to coercive means. When the Act was finally held, under the military's watchful eyes, 1,000 carefully selected tribal leaders unsurprisingly opted for their homeland to remain a province of Indonesia. ${ }^{10}$ In the years leading up to the referendum, groups of urban Papuans staged demonstrations demanding genuine self-determination; others entered the forest and took up arms. ${ }^{11}$ According to one account, it was the Indonesian authorities who gave the budding movement its name: the Free Papua Operation or OPM. ${ }^{12}$

The flag raising on Biak coincided with demonstrations in several of Irian Jaya's other major cities: Sorong, Jayapura, and Wamena. The twenty-seventh anniversary of

\footnotetext{
${ }^{8}$ See Robin Osborne, "The OPM and the Quest for West Papuan Unity," in Between Two Nations: The Indonesia-Papua New Guinea Border and West Papuan Nationalism, ed. R. J. May (Bathurst, Australia: Brown, 1986), p. 2; see also Robin Osborne, Indonesia's Secret War: The Guerrilla Struggle in Irian Jaya (Sydney: Allen and Unwin, 1985).

${ }^{9}$ For a discussion of the Act of Free Choice (AFC), as stipulated under the New York Agreement, see Peter Savage, "The National Liberation Struggle in West Irian: From Millenarianism to Socialist Revolution," Asian Survey 18, 10 (1978): 986. "The organization of the AFC was to include: (a) consultations with the representative councils of the nine regions on the procedures and methods to be followed for ascertaining the freely expressed decision of the people; (b) a clear formulation of whether or not Indonesia was to continue in control; (c) a guarantee of the eligibility of all indigenous inhabitants to participate in the AFC, which was to be carried out in accordance with international practice; and (d) the establishment by Indonesian-Netherlands consultation of the exact time of the AFC, which was to take place before the end of 1969. Indonesia under article XXII of the Agreement also undertook the following, without which the previous provisions would be meaningless: to guarantee the human rights of the inhabitants of West Papua New Guinea [sic], including the rights of free speech and freedom of movement and assembly."
}

In 1962, the head of the Indonesian mission to UNTEA and Deputy Minister of Foreign Affairs "suggested that a plebiscite through suffrage would be too difficult, and that the wishes of the people should be determined through consultation [musjawarah] with community leaders." Between 1962 and 1968, local leaders were pressed into signing resolutions supporting Indonesian rule and deeming the referendum unnecessary. Ibid., p. 985. See also John R. G. Djopari, Pemberontakan Organisasi Papua Merdeka (Jakarta: Rasindo, 1993), pp. 72-3.

10 Although the settlement called for UN supervision, the only observers allowed to be on hand for the plebiscite were a Bolivian diplomat-who spoke no Indonesian--and a skeletal staff. See Savage, "The National Liberation Struggle in West Irian," pp. 986-7.

11 See "Former Governor of West Irian Interviewed by TAPOL," Tapol Bulletin 48 (November 1981): 9-10.

12 See Djopari, Pemberontakan Organisasi Papua Merdeka, p. 100. As far as titles go, the direct precursor to the OPM was the Organisasi dan Perjuangan Menuju Kemerdekaan Papua Barat, whose leader, Terianus Aronggeor, was captured in Manokwari in 1964. The name OPM gained currency in 1965, after Permenas Ferry Awom launched a guerilla campaign against the Indonesian army. 
the OPM's Declaration of West Papuan Independence fell on July 1, 1998, a little over a month following the resignation of Indonesia's President Suharto after thirty-three years in office. ${ }^{13}$ The Indonesian province of Irian Jaya was born during the same decade as Suharto's "New Order" regime. Suharto commanded a military mission intended to retake "West Irian" in 1961, four years before coming to power in the aborted coup and state-sponsored massacres that destroyed the Indonesian Communist Party and forced the Republic's first president to resign. In Irian Jaya, Suharto's sudden removal from public office served to revive old hopes. Irian Jayans had no doubt heard of the riots that swept Jakarta and other major Indonesian cities in May 1998, as well as the peaceful student protests that preceded them. Those with televisions may have seen images of the students who occupied the parliament building during Suharto's final days. Between rounds of chanting and singing, the protesters chatted with young soldiers, who smiled, their weapons idle at their sides. The brutal response of Indonesian troops to the pro-independence protests in Irian Jaya provided a lesson in the limits of reformasi, as this brave new era in Indonesian politics has been dubbed. "These people were not demanding reform; they wanted a separate state," the commander in Biak explained. ${ }^{14}$ Against such a "betrayal of the nation," added General Wiranto, the chief of the Indonesian Armed Forces, "firm action" was required. ${ }^{15}$

One need not look far for a straightforward explanation of the flag raising and its aftermath on Biak. "This really isn't a new problem," said one Biak friend, voicing a sentiment widely shared in the province. "People want a fair referendum so they can decide their fate." It is not surprising that Indonesia's new rulers oppose such a proposal. Shortly after Suharto's fall, several members of the US Congress sent a letter to B. J. Habibie, the current president, and Amien Rais, his most powerful opponent, calling for dialogue on the political status of East Timor and Irian Jaya. While Indonesia has proven open to negotiations on East Timor, both Habibie and Rais indicated in July 1998 that they would draw the line at Indonesia's resource-rich easternmost province. ${ }^{16}$ In the fall, there was some softening of this stance, with plans going ahead for a "national dialogue" between Irianese leaders and the Indonesian national government. ${ }^{17}$ But when one hundred representatives from the province

13 Ibid, p. 116. See also Osborne, "The OPM and the Quest for West Papuan Unity," p. 55.

14 See "Irian Tribes Defy Slaughter," Sydney Morning Herald, July 8, 1998.

15 Ibid. See also “Focus: Indonesian Troops Tackle Fresh Irian Rally," July 7, 1998.

16 See "Indonesia's Black Death," Sydney Morning Herald, November 11, 1998.

17 See "Jakarta Ready to Hold Dialogue on Irian Jaya: MP," AFP, October 19, 1998; "Habibie Setuju Berdialog dengan Tokoh Irian Jaya," Kompas, October 27, 1998; "Irianese Want More than Pledge of Dialog," Jakarta Post, January 23, 1998. Spearheading the campaign for a national dialogue is FORERI, Forum Rekonsiliasi Rakyat Irian Jaya (The Forum for the Reconcilation of the Irian Jayan People), which came into being in the wake of the July demonstrations, following a fact-finding mission led by the deputy speaker of the national parliament, Abdul Gafur. FORERI's founding members include Herman Saud, Synod Chair of the Irian Jaya Gospel Church (Gereja Kristen Injil Irian Jaya); Leo Laba Lajar, Bishop of Jayapura; Theys Eluway, Chair of the Irian Customary Council Institute (Lembaga Dewan Adat Irian); Tom Beanal, Chair of the Foundation for Customary Consultation of the Amungme Tribe (Lembaga Musyawarah Adat Suku Amungme), Presidium member of WAHLI, Indonesia's pre-eminent environmental organization, and former delegate to the provincial parliament; Martinus Werimon, Chair of the Student Senate of Cendrawasih University; the Chair of the Student Senate of I. S. Kijne Seminary of the GKI; and feminist activist Yusan Yeblo. 
presented Habibie with a demand for independence in a February 26 "pre-meeting" in Jakarta, the president told them to go home and think again. ${ }^{18}$ Reports that the armed forces had a hand in orchestrating the July demonstrations in Irian Jaya are not entirely implausible. Military officers have a stake in the designation of certain provinces as "unstable." Former commanders often live out their retirement in East Timor or Irian Jaya so they can reap the harvest of profitable business deals made in the areas under their command. While the assault came later than it would have under Suharto-when flag raisings lasted minutes, not days-the brutal treatment of the demonstrators followed a familiar script, in which soldiers protect the Republic from the enemy within.

I would not want to underplay the long history of broken promises, corruption, and discrimination that has led to demands for an independent West Papuan state. Nor would I want to downplay the collusion of individual, institutional, and international interests in the continuance of Indonesian rule. At the same time, I would not want to leave the impression that the "symbolic" and the "political" aspects of the incident belong to separate domains. According to the commander in Biak, only fifty of the demonstrators were "hardcore" separatists; the other three hundred were "deluded" by promises of miraculous improvements in conditions and the belief that something religious was going on. ${ }^{19}$ A critique of this attempt to explain away the "disturbance" must go further than asserting that religion provided a "language" for the protestors. An interpretation of the flag raising must pay heed to the metaphysical underpinnings of all modern states, be they imaginary or "real."

In an intelligent, meticulous report on the July demonstrations, Sidney Jones of Human Rights Watch notes, quite accurately, that the pro-independence actions in Irian Jaya were "not all wholly peaceful." 20 This comment confirms what upon reflection should seem obvious. Violence was not simply a means to an end in the flag raising (and flag lowering); it was crucial to the very meaning of both gestures. What was at stake in that contested piece of cloth was Indonesia's very status as a state, as defined by its ability to maintain a monopoly over the legitimate use of force. ${ }^{21}$ This monopoly was challenged not only by the demonstrators' attack on the police, but also

\footnotetext{
${ }^{18}$ See "Irianese Leaders Want Control of Their Land," Jakarta Post, February 27, 1999; "Habibie about Irian: Contemplate Again That Demand for Independence," Kompas Online, February 28, 1999. For an English translation of the statement delivered to Habibie, see "West Papuans Demanding for Free West Papua," Kabar Irian, February 17 newsgroup posting. The statement stipulates that if their demand for independence is not met, that the "people of West Papua" will boycott the general elections in 1999. Freddy Numberi, the current governor, has interpreted Habibie's response as implying the case for independence is closed; his own proposal calls for greater autonomy. See "Irian Governor Calls for 'Special Autonomy,", Media Indonesia, March 11, 1999; "Irian Jaya: Government Rejects Demand for Independence," Antara, March 13, 1999; "Government Rejects Demand for Irian Independence," Kompas, March 15, 1999. On the threats received by members of the delegation upon their return to Jayapura, see Amnesty International, "Fear for Safety/Threats and Intimidation: Hermanus Wayoi, Don Flassy, Workers at ELS-HAM, a local human rights organizations," AI Index: ASA 21/16/99, March 9, 1999.

19 See Cendrawasih Pos, July 14, 1998: 1.

20 "Indonesia: Human Rights and Pro-Independence Actions in Irian Jaya."

21 See Max Weber, "Politics as a Vocation" in From Max Weber: Essays in Sociology, ed. H. H. Gerth and C. W. Mills (London: Routledge and Kegan Paul, 1970); see also Walter Benjamin, "Critique of Violence" in Reflections: Essays, Aphorisms, Autobiographical Writings, Edmund Jephcott, trans. (New York: Schocken, 1978), pp. 277-300.
} 
by the oath that legitimized the assault. The demonstration began, one should recall, with a performative: a forceful, self-fulfilling gesture. ${ }^{22}$ Karma's declaration created its own truth by constituting its own subject, the "West Papuan" people in whose name he promised never to abandon the flag. For a brief period, in one small corner of Indonesia, the demonstrators violently established the legitimacy of an alternative regime.

If the flag raising was a "performative," then the shootings could be read as an attempt to prevent the founding of West Papua from becoming "felicitous," that is, a speech event undertaken in a discursive context that guarantees that such an oath will shape future action. Against the soldiers' guns, the demonstrators mobilized higher powers to ground their tautological words and deeds: "God, the Father, Son and Holy Ghost," who were named as witnesses to the pledge. At the Biak water tower, as elsewhere, the violent birth of a nation entailed an appeal to the transcendent. ${ }^{23}$ But the logic of the nation-state only captures one aspect of the confrontation, which brought together a multiplicity of conceptions of the relationship of violence to order, origins, and truth.

In this essay I explore the intersection between these multiple conceptions. I offer a tentative answer to a question many on Biak found important: what gave those young demonstrators the courage to face up to armed soldiers? I seek a response not only in Papuan nationalism and the recent experience of Indonesian rule, but also in the long tradition of Biak millenarianism. I show how this tradition finds its basis in everyday practices that transform what is foreign into a source of value, authority, and prestige. From foreign porcelain to government slogans, Biaks have tended to valorize objects and texts that they take as traces of encounters with dangerous outsiders. The violence of a clash between worldviews is posited in many of the processes through which Biaks create their identities and seek status and power. This valorization of the foreign, taken alone, cannot account for the pro-independence protests in Biak.

22 On performatives, see J. L. Austin, How to Do Things with Words (London: Oxford University Press, 1976); John Searle, "What is a Speech Act?" in Language and Social Context, ed. Pier P. Gigioli (London: Penguin, 1965), pp. 136-54; Jacques Derrida, "Signature, Event, Context" in Margins of Philosophy, Samuel Weber, trans. (Chicago: University of Chicago Press, 1982), pp. 307-330. The relationship between violence and order in a foundational moment, such as that posited in the flag raising, is over-determined. Some writers on violence have stressed its own performative structure, arguing that the violent act both signifies and enforces its own legitimacy by providing a pre-emptive strike that silences dissent. See David Riches,

"Aggression, Warfare and Violence: Space/Time and Paradigm," Man N. S. 26: 281-98 and Christian Krohn-Hansen, "The Anthropology of Violent Interaction," Journal of Anthropological Research 50 (4): 367 382. Legally sanctioned violence, in turn, refers back to an equally performative act of force: the law founding utterance that creates its own legitimacy, after the fact. On this problem, see Jacques Derrida, "Force of Law: The 'Mystical Foundations of Authority"' in Deconstruction and the Possibility of Justice, ed. Drucilla Cornell, Michel Rosenfeld and David Gray Carlson (New York and London: Routledge, 1996), pp. 3-67.

23 See B. Honig, "Declarations of Independence: Arendt and Derrida on the Problems of Founding a Republic," American Political Science Review 85, 1 (1991): 97-113 and Benjamin Lee, Talking Heads: Language, Metalanguage and the Semiotics of Subjectivity (Durham: Duke University Press, 1997), pp. 338341. Lee describes the double lines of authority that underwrite the US Declaration of Independence, one stretching "through the self-evident laws of nature to God, the ultimate, eternal, transcendental countersignatory"; the other "to the just announced and contested 'good people of the colonies. The radical performativity of the latter is legitimated by the transcendent authority of the former." Ibid., p. 328. 
Nevertheless, at critical moments, a distinctively messianic vision has shaped the way Biaks envision and pursue political change.

For many Biaks, "God, the Father, Son and Holy Ghost" is really Manarmakeri, the Biak ancestor responsible for the wealth and power of outsiders. However Philip Karma's oath may have followed a familiar model for the founding of a nation; in the very act of appealing to the divine, Karma may have allowed for a shift into a narrative premised on very different assumptions on the nature of power, space, and time. But if I approach the flag raising as a millennial moment, I also pay heed to the equally violent narratives of transformation promulgated by the Indonesian regime. To set the stage for this analysis, I begin by briefly considering the broader institutional forces that have encouraged Biaks to participate in the Papuan nationalist movement, from its earliest stages to the present day.

\section{Papuan Nationalism and Biak Cosmopolitanism}

Rising from the Pacific at the mouth of Cendrawasih Bay, roughly two hundred kilometers off the New Guinea mainland, three small islands and a scattering of atolls make up the Indonesian Regency of Biak-Numfor. Over the territory's colonial and postcolonial history, the inhabitants of these islands have sometimes appeared as exemplary of "Papuan" or "Irianese" identity, sometimes as the exception that proves the rule. Biak speaking seafarers were among the first of New Guinea's inhabitants to confront European traders, missionaries, and officials, by virtue of their longstanding tributary relations with the Moluccan Sultanate of Tidore. By 1920, the Netherlands Indies military had "pacified" the islands. By the early 1930s, the vast majority of Biaks had converted to Protestantism, and almost every village featured a mission church and school. In the late 1940s, one official observed that illiteracy was "virtually nonexistent" among Biak men below the age of thirty-five. ${ }^{24}$ At a time when the ancestors of today's Dani and Amungme had yet to encounter Europeans, Biak evangelists were spreading the Gospel along New Guinea's northern coast. Biak's longstanding experience with outsiders made islanders fodder for early Dutch descriptions of the custom and character of "the Papuan." 25 In the 1950s, when the Dutch retained western New Guinea as a separate colony, Biaks and other coastal Papuans continued to play a central role in colonial representations of the territory's natives, as well as in policies designed to cultivate an educated Papuan elite. Dutch propaganda featured before and after photographs, opposing scantily clad tribesmen from the highlands to smiling coastal workers. ${ }^{26}$ Figures from Biak, Sentani, and other places with a long history of contact stood in for the "modern" Papuan this new civilizing mission promised to produce.

\footnotetext{
24 See Jan Victor de Bruyn, "Jaarverslagen 1947 en 1948 van Onderafdeling Biak," Nienhuis Collectie van de Department van Bevolkingszaken, Nummer Toegang 10-25, Stuk 188 (The Hague: Algemeene Rijksarchief, 1948), p. 7.

25 "De bevolking van Biak en het kolonisatievraagstuk van Noord Nieuw-Guinea," Tijdschrift Nieuw Guinea 1: 169-177.

26 See, for example, Vademecum voor Nederlands-Nieuw-Guinea (Rotterdam: New Guinea Institute in cooperation with the Ministry of Overseas Territories, 1956).
} 
By making "progress" appear as the outcome of Dutch intervention, these images obscure the accidents of geography and history that have made places like Biak and Jayapura what they are today: relatively urban, cosmopolitan, multiethnic sites in a vast, sparsely populated province. During World War II, when the war in the Pacific started to turn against Japan, the Occupation forces began building what is now the longest runway in Indonesia on Biak Island; the Allies completed the project during MacArthur's famous "island hopping" campaign, after driving out the Japanese. ${ }^{27}$ After the war, the Dutch expanded the airport and the surrounding settlement, building on the foundations of the American military base. Today, in addition to an international airport, Biak City boasts a port, a canning factory, a plymill, three markets, two supermarkets, numerous shops, hotels, restaurants, and karaoke bars, three military posts, and countless government offices. It is home to Makassarese and Sino-Indonesian merchants, officials and soldiers from Java, Bali, Sumatra, Ambon, and other distant Indonesian islands, a handful of Western visitors, and a large community of Irian Jayans from other tribes. Urban Biaks include everyone from the Regent to NGO directors to teachers, day laborers, taxi conductors, nurses, and lowpaid government clerks. Among their numbers is a growing population of young, unemployed high school graduates and drop-outs, many of whom while away their days at the taxi terminal near the main market. Some are waiting for job openings in the civil service, which, despite its expansion under the New Order, can absorb only a fraction of those who apply. In addition, at any one time, Biak City is a temporary home to scores of rural Biaks: fishermen selling their catch, subsistence farmers marketing their extra fruit and vegetables, seasonal construction workers, and children staying with relatives while they attend school. In recent years, the Indonesian government has extended roads and bridges to distant coastal villages, making it easier for villagers to travel to market and for elite Biaks to build retirement homes on their clan land. With luck, one can make it to Biak City from almost anywhere in the islands in less than five hours. In the early 1990s, when Biak was a refueling stop on the route between Los Angeles and Jakarta, Honolulu was less than twelve hours away. Biak bureaucrats and academics, traveling to Jakarta, Townsville or Leiden, sometimes boarded these international flights.

Below, I discuss in detail the distinctive values that orient Biaks' participation in social arenas that extend far beyond the local setting. But at this point, it is worth noting how conditions in Biak bring into sharp relief grievances shared by other Irian groups. Biak-Numfor is the most densely populated regency in Irian Jaya, and one of the least fertile. Yet in recent years, Biaks have had to surrender clan land for a range of projects, from a satellite launcher to a transmigration site to a five-star resort. Biak fishermen complain of declining yields as commercial trawlers deplete the coastal stocks. As elsewhere in the province, non-Irian Jayans dominate the urban economy, owning everything from the taxis villagers ride to town to the shops where they buy sugar and rice. ${ }^{28}$ Makassarese traders monopolize the choicest stalls in the central

27 See Robert Ross Smith, The US Army in World War II: The War in the Pacific, vol. 3: The Approach to the Philippines (Washington, D.C.: Office of the Chief of Military History, 1953), pp. 280-396.

28 On the role of migrants in the provincial economy, see R. Garnaut and C. Manning, Irian Jaya: The Transformation of a Melanesian Economy (Canberra: ANU Press, 1974) and Chris Manning and Michael Rumbiak, "Irian Jaya: Economic Change, Migrants, and Indigenous Welfare" in Unity and Diversity: 
market, leaving local producers to crouch along the outer aisles or in the dirt outside. Local residents also find themselves pushed to the margins in the competition for government benefits. To the consternation of Biak parents, the children of migrants from outside the province often win jobs and scholarships reserved for the locally born. Biaks are well aware of the province's vast reserves of minerals and natural gas; some have seen the Freeport mines first hand. They are also aware that public services in the province are woefully inadequate. Even in this relatively accessible regency, classrooms stand empty, and clinics are understaffed and under stocked. Above all, as I elaborate below, Biaks share with other Irian Jayans indelible memories of state terror. Some still carry scars (and in some cases bullets) from the turbulent 1970s, when the Indonesian military attacked North and West Biak villages to flush out armed guerillas. Under the New Order, activists who criticized government policies were often accused of harboring separatist sympathies. Biaks learned from decades of extra-judicial violence that the label OPM could be the "kiss of death."29

But it is not enough simply to point to this memoria passionis, "history of suffering," to understand why the dream of self-determination has not only survived, but thrived in Biak and Irian Jaya more generally. ${ }^{30}$ The past four decades have introduced a range of shared experiences that have made an independent West Papua imaginable for growing numbers of the province's inhabitants. On the one hand, one must consider the circumference of the "administrative pilgrimages" taken by the provincial elite. ${ }^{31}$ No matter how much overseas training they may have received, the majority of Irianese bureaucrats, soldiers and academics have pursued their careers in the space between Sorong (not Sabang!) and Merauke, i.e. within the borders of what is now Irian Jaya. ${ }^{32}$ The same elite has long sustained the separatist movement, both in Irian Jaya and overseas. $^{33}$ While Biaks have no monopoly on OPM leadership-or high-ranking government posts-suitable examples emerge from their ranks. Marcus Kaisiepo, West

Regional Economic Development in Indonesia since 1970, ed. Hal Hill (Oxford: Oxford University Press, 1991), pp. 77-106.

29 See "OPM is "The Kiss of Death,; Says MP," Tapol Bulletin 43 (January 1980): 5.

${ }^{30}$ See J. Budi Hernawan OFM and Theo van den Broek OFM of the Secretariat for Justice and Peace of the Jayapura Diosese, "Dialog Nasional Papua: Sebuah Kisah 'Memoria Passionis," Tifa Irian, March 12, Internet posting March 25.

31 See Benedict Anderson, Imagined Communities (New York: Verso, 1991), pp. 53-56. For this analysis, I am also drawing on pp. 170-178, where Anderson explicitly considers the roots of Papuan nationalism in provincial icons and institutions.

32 Some Biak leaders claim that an important source of resentment lies in the fact that western Indonesians are frequently sent to serve in Irian Jaya, but Irianese officials are rarely sent to serve in western Indonesian provinces.

33 See "Former Governor of West Irian Interviewed," Tapol Bulletin 49 (January 1982): 5, where D. Kafiar, a Papuan refugee, comments on the composition of the OPM in the field. "Many come from the towns. Young people and government officials from the lowest to the highest ranks." See also Amunggut Tabi, Kabar Irian, January 1, 1999. In this posting, which clarifies "the aspirations of the West Papuan People and the position of the OPM" one scarcely gets the sense that the provincial elite is to be criticized for working for the Indonesian state. " 2 . It is true that some West Papuans currently enjoy Indonesian government positions and a measure of wealth and freedom, but deep within our hearts we will never possess any real peace or satisfaction until all our people are free, and this is the essence of our struggle ... 8. All West Papuans will be treated equally in the new nation, including persons currently serving under the Republic of Indonesia, such as the current governor of Irian Jaya and the rector of Cendrawasih University." 
Papua's first "president-in-exile," was a graduate of the Netherlands New Guinea School for Native Administrators; Permenas Ferry Awom, leader of the 1965 Manokwari rebellion, was a member of the Papuan Volunteer Brigade; Seth Rumkorem, the "brigadier general" from the OPM faction that declared independence in 1971, was an officer in the Indonesian army; Arnold Ap, promoter of Papuan culture and martyr to the separatist cause, was a lecturer at the provincial university and the curator of a museum of provincial art. ${ }^{34}$ While it seems likely that he acted on his own, without the involvement of established separatist groups, Philip Karma, the organizer of the Biak flag raising, fits the profile of a typical OPM leader. ${ }^{35}$ Son of the first Biak to serve as a regent, Karma was, until his arrest, a mid-level official in the provincial administration. Like so many nationalists before him, he is the product of the system he risked his life to overturn. On the other hand, one must pay heed to the unifying effects of provincial initiatives from internet newsgroups to newspapers like the Cendrawasih Pos and Tifa Irian to government sponsored contests promoting provincial costumes and dances. These technologies account for how Irian's highly diverse population has come to express a sense of shared purpose, despite the disunity that has often plagued the OPM. ${ }^{36}$

The new imaginings made possible by contemporary institutions and modes of communication played a crucial role in the flag raising on Biak. But there is more to the story, as the rest of this essay should confirm. My understanding of the July protest is based on the straightforward proposition that it is possible for people to invoke different identities and address different audiences, both across settings and in the course of single social interaction. ${ }^{37}$ Whether one has in mind the reading of a newspaper or the raising of a flag, representations are always in some sense underdetermined. ${ }^{38}$ Although interpretations of a performance are always contextually based, no single context is ever exhaustive of all the possible meanings of an event. This is not to deny that some readings are more powerful or pronounced than others; the challenge is to consider how contrasting and even contradictory frameworks can

\footnotetext{
34 On the backgrounds of various OPM leaders, see Djopari, Pemberontakan Organisasi Papua Merdeka, pp. 100-131; Nonie Sharp with Markus Wonggor Kaisiepo, The Morning Staf in Papua Barat (North Carlton, Australia: Arena, 1994); Anderson, Imagined Communities, p. 178.

35 Neither the Papuan exiles I spoke with in Holland in September, nor the human rights activists I later consulted, were aware of any connection between Philip Karma and any pre-existing separatist organizations. I was told that Karma only decided to organize the demonstration after arriving on Biak, where he had come to visit his ailing father.

${ }^{36}$ Recent events provide numerous examples of such expressions of shared purpose. In May of 1998, Irianese college students and human rights advocates rallied in Jayapura and Jakarta for the withdrawal of troops from the Central Highlands. These demonstrations followed the widely publicized issuing of a report by Irianese religious leaders to the National Human Rights Commission documenting abuses in Mapnduma, an isolated region whose inhabitants the vast majority of Irianese will never meet. See Human Rights Watch, "Indonesia Alert: Trouble in Irian Jaya." The importance of communications technology to the Papuan nationalist movement is reflected in a recent posting by the OPM spokesman, Amunggut Tabi, calling for support so he can establish an email network for West Papuan tribal leaders. See Kabar Irian, March 15, 1999.

37 See Joseph Errington, Shifting Languages: Interaction and Identity in Javanese Indonesian (Cambridge: Cambridge University Press, 1998), especially pp. 4-5.

38 See Webb Keane, Signs of Recognition: Powers and Hazards of Representation in an Indonesian Society (Berkeley: University of California Press, 1997).
} 
intersect in historically grounded and systematic ways. Among Irian Jayans, one sees evidence of such an intersection on the provincial level, where nationalist pronouncements reflect the influence of a long history of mission involvement. Papuan separatists may describe themselves as members of a global order of nations, but they also depict their "imagined community" in explicitly Christian terms. ${ }^{39}$ In the case of Biak, the very values that have prompted the islanders to participate in provincial struggles underwrite a resilient set of millennial expectations. Sometimes, many Biaks do seem to envision themselves as part of a politically silenced Papuan nation advancing in "homogeneous, empty time." But there is a broadly shared tendency to interpret international acknowledgment of this identity as initiating an eschatological transformation. From this perspective, independence appears as the utopian moment when Biak will be revealed as the true origin of earthly power. At other times, Biaks downplay this millennial/nationalist vision through practices that posit a very different sense of self. Nationalism is often depicted as involving the recognition of an interiorized locus of identity. ${ }^{40}$ In Biak, this interiority stands in tension with the assumption that one gains status from being foreign: different from oneself and one's peers.

Later in this essay, I develop this argument by looking more closely at the character of Biak sociality. But first, I attend to another force of critical importance in the flag raising and its aftermath: the Indonesian state. John Djopari has noted that Irianese youths who have fled Indonesia finally feel free to express their convictions. "Perhaps when they are in Irian Jaya they restrain themselves," he remarks. ${ }^{41}$ With the end of the New Order, Biaks and other Irian Jayans suddenly found themselves living in what they took to be a new and different land. Unfortunately, the changes were not as radical as they may have seemed, as I suggest in the following section, where I examine the logic underlying the military's brutal suppression of the demonstration. On Biak at least, state terror has persisted in uncannily familiar forms.

\section{The New Order and the Ends of Violence}

When one considers the conditions under which President Suharto ruled, it is surprising that his fall did not come sooner. The New Order's longevity, as John Pemberton has noted, did not rest solely on open coercion or threat. To account for the quiescence that reigned in much of Indonesia for the period of Suharto's rule, Pemberton looks not to a "culture of terror," but a "relatively muted form of terror that might become culture: the repression of fear that customarily secures, over time, an appearance of normal life." 42 With fear transposed into anxiety over the specter of cultural incompletion, the Javanese population at Indonesia's core embraced the

\footnotetext{
${ }^{39}$ See Tabi, Kabar Irian, January 1, 1999. "The future nation of West Papua shall not tolerate military dictatorship of any kind, but shall be ruled by civilians. It will be the only nation on Earth to acknowledge the Bible as exclusive source for all its laws."

${ }^{40}$ See James Siegel, Fetish, Recognition, Revolution (Princeton: Princeton University Press, 1997); John Pemberton, On the Subject of "Java" (Ithaca: Cornell University Press, 1994), p. 134, and Marilyn Ivy, Discourses of the Vanishing: Modernity, Phantasm, Japan (Chicago: University of Chicago Press, 1995).

${ }^{41}$ See Pemberontakan Organisasi Papua Barat, p. 151.

42 See Pemberton, On the Subject of "Java," p. 8.
} 
official virtues of order, stability, and progress. Seeing themselves from the perspective of the abstract authority of "custom," they engaged in compulsive rounds of statesanctioned rituals. Mobilized to create the impression of an imperishable order, the transcendent realm of "culture" bridged the ruptures of colonial and postcolonial history. Building museums filled with new heirlooms and improved versions of old monuments, the New Order subsumed old and new, originals and replicas, into an abstract topology of clearly demarcated regional cultures and selves.

When I was conducting fieldwork on Biak from 1992 to 1994, I found no dearth of expressions of the official narratives of culture and development that Pemberton so astutely dissects. The "security approach" had given way to the "prosperity approach," I was told, by officials committed to the revival of Biak "tradition" and the entry of the population into the ranks of orderly Indonesian subjects. ${ }^{43}$ But alongside official discourses that assured Biaks that order and progress was what they desired was another set of narratives with a more sinister message for those who strayed from the official path. While I was free to travel to most parts of the island, I was warned against venturing to West Biak, a place that remained "disturbed" by the presence of an OPM commander who had managed to survive decades of counterinsurgency operations on the island. In 1990, Indonesian troops shot the guerilla's nephew, who had fled to the forest after a flag raising in a West Biak village. Carrying their victim's severed head aloft on a pole, the troops marched home along the densely populated coast. ${ }^{44}$ In this grisly spectacle, the soldiers took on the lethal power of the headhunters who once inhabited the island. ${ }^{45}$ The state had the capacity not only to annihilate their "primitive" rivals, but also to tap their savage, excessive power.

The events of last May decisively shattered the illusion that the New Order was eternal. But the logic that linked order and violence under Suharto is still not a thing of the past. Evidence has emerged of military involvement in the rape and murder of ethnic Chinese Indonesians in Jakarta and other major cities in the weeks leading up to Suharto's fall. ${ }^{46}$ The riots could be read as an effort to repeat the violent moment of the New Order's birth, when certain factions orchestrated an eruption of local animosities, then intervened to restore the law. The military on Biak seems to have tried to follow a similar script. In the days following the flag raising, the provincial paper reported on a counter-demonstration carried out by villagers from West Biak. ${ }^{47}$ Other sources suggest that the military not only coerced West Biak villagers into protesting the flag raising;

\footnotetext{
43 See Danilyn Rutherford, "Of Birds and Gifts: Revising Tradition on an Indonesian Frontier," Cultural Anthropology 11 (4): 577-616.

44 See Amnesty International, "Indonesia: Continuing Human Rights Violations in Irian Jaya," Country Dossier ASA 21/06/91, Microform E151, 1991, p. 25.

45 Compare James T. Siegel, A New Criminal Type in Jakarta: Counter-revolution Today (Durham: Duke University Press, 1998), pp. 8, 90-119; see also Janet Hoskins, "Introduction: Headhunting as Practice and Trope" in Headhunting and the Social Imagination in Southeast Asia, ed. Janet Hoskins (Stanford: Stanford University Press, 1996), pp. 31-37 and Anna Lowenhaupt Tsing, In the Realm of the Diamond Queen (Princeton: Princeton University Press, 1993), pp. 72-103.

${ }^{46}$ See John T. Sidel, "Macet Total: Logics of Circulation and Accumulation in the Demise of Indonesia's New Order," Indonesia 66 (October 1998): 159-196, esp. 179-182.

47 See Cendrawasih Pos, July 14, 1998: 1; see also TAPOL, “Situation Tense in Biak," Unpublished internet posting, July 5, 1998.
} 
they also set in motion a plan to bring them to the site of the demonstration. ${ }^{48}$ Armed with axes and machetes, the West Biaks were supposed to start a battle with the demonstrators, giving the security forces an excuse to step in. ${ }^{49}$

Few Biaks reading of the counter-protests would have been ignorant of the heavy price West Biaks have paid for sheltering the last armed fugitive on the island. Equally few could have avoided hearing of the abuse suffered by the protesters and others unlucky enough to be near the water tower at the time of the attack. Two sets of narratives told different stories about the event, the first depicting the state's lethal power over its critics, the second assuring the faithful that chaos had been firmly, but gently, contained. The effectiveness of their interplay was evidenced in the aftermath of the shootings. Only a handful of families dared to report that their children were missing. The lack of complaints was used as evidence that no abuses had occurred. The authorities' effort to explain the sea-borne bodies as victims of a distant disaster was more than an exercise in damage control. It was an explicit demonstration of the state's monopoly over the giving and taking of identities, as well as lives.

Clearly, the tsunami was a stroke of good luck for the authorities; it gave them a chance to cover the traces of the massacre by providing a "natural" explanation for any recovered victims. But the argument that the corpses could not be the demonstrators because they were not Indonesians suited the strange logic of Indonesian state terror and sharpened the point of the military attack. Jim Siegel has recently pointed out that Indonesians have tended to "kill in their own image."50 Extra-legal violence against separatists, communists, and criminals alike is not intended to purify the nation of alien elements, but to demonstrate the state's ability to appropriate their potency, i.e. to "nationalize death." ${ }^{51}$ The soldiers who shot the young Biaks acted on the assumption that their victims belonged within the Indonesian state. This is not to deny that intruders of various sorts took part in the affair, including the American politicians mentioned above, whose letter reached the province, where it circulated widely. The authorities presented themselves as defusing these disruptions by translating them into manageable terms. Just as the authorities reassured the alarmed villagers by determining the true identity of the foreign corpses, they clarified the true meaning of the foreign letter, which called for limited autonomy, not independence, they claimed. Against the public secret of the state's "world destroying"-and order confirming-violence, the official version made violence alien to the law. ${ }^{52}$

\footnotetext{
48 See Human Rights Watch, "Indonesia: Human Rights and Pro-Independence Actions in Irian Jaya."

49 I was told that the West Biaks agreed to play their part in the drama only after the commander promised to let them recover from the forest the remains of loved ones killed by the military in earlier decades. The grim charade allowed the bereaved to demonstrate their loyalty. Otherwise, the simple act of burying the dead would have branded them as opponents of the state.

50 See Siegel, A New Criminal Type in Jakarta, p. 1.

51 lbid., p. 108.

52 See Elaine Scarry, The Body in Pain: The Making and Unmaking of the World (New York and Oxford: Oxford University Press, 1985).
} 


\section{Biak and the Ends of Order}

Among Biaks, one encounters a starkly different conception of the relationship between violence, order, and origins. A few months after I began fieldwork, I found myself talking with a new friend about her husband, a mild-mannered teacher whom I had met on several occasions. Jan was "jahat," Fransina told me, using an Indonesian word meaning "wicked" or "evil." Just as surprising as Fransina's choice of words was the boastful tone of her voice. As time went on, I met other Biaks who used the adjective, jahat, as a compliment. A jahat person, though for the most part reserved, was capable of outbursts of violent rage ${ }^{53}$ This capacity for violence was not only admired in fishermen or hunters. Top officials liked to describe themselves as present day mambri, the fearsome "warriors" for whom Biak was once renowned.

The other way that top officials liked to describe themselves was as amber beba, "big foreigners." A word meaning "Westerner, non-Irianese Indonesian, civil servant, or individual with special skills," amber also can be used as an adjective to describe the outside realms where Biaks seek wealth and prestige. From the first appearance of Biak-speaking seafarers in European records, one finds an association of the foreign with both violence and value. Powerful outsiders, ranging from the Sultan of Tidore, to whom Biaks delivered tribute, to the agents of the Dutch colonial state, attracted both fear and desire. Today's Biaks recreate the linkage between violence and value in the most intimate arenas of everyday life. Biak kinship divides the islanders into patrilineal, exogamous clans. Where same sex siblings tend to be rivals for clan resources, cross-sex siblings regard each other with longing and love. Elsewhere I have analyzed the connection between this affection and the inflationary logic of Biak exchange. ${ }^{54}$ The status of a Biak brother-and his clan, more generally-depends on his and his clan's ability to give their affines more foreign valuables than they receive as bridewealth. Children become "foreigners" by virtue of the gifts their mother elicits from her brothers, who acquire this surplus through ongoing "raids" on foreign lands. Biaks speak of these gifts as motivated by a brother's "love" for his sister. But the aesthetics of the feasts that sisters host to elicit foreign valuables from their brothers portrays the giving of these prestations as an act of force. Everything from the guests' noisy procession to the dance ground to the songs they sing when they arrive recalls the violence of an encounter with the new.

But it is not only at feasts that Biaks stress the violence and value of the foreign. They confirm these qualities in narratives recounting the origins of social groups. Many stories about the founding of lineages, for instance, focus on the actions of mambri, the warriors mentioned above. In the past, warriors offered themselves for hire to feuding clans. The offended party got the warrior drunk, then spat in his cup to insult him, before sending him off in the direction of the offending village. Like a detonated missile, the infuriated warrior killed the first person to cross his path. The victim's relatives avenged the death by hiring another warrior, thus keeping the violence in circulation. But what also circulated were alliances. Clients compensated warriors by

\footnotetext{
53 Such outbursts not only command respect; they are considered critical to the resolution of disputes. See Danilyn Rutherford, Raiding the Land of the Foreigners: Power, History and Difference in Biak, Irian Jaya, Indonesia (PhD dissertation, Cornell University), p. 202.

54 See Danilyn Rutherford, "Love, Violence and Foreign Wealth: Kinship and History in Biak, Irian Jaya," Journal of the Royal Anthropological Institute 4 (2): 255-281.
} 
giving them their sisters to marry; warriors gave their own sisters to their victims' clans to compensate for the loss of life. Through these unions-and the brother-sister bonds they mobilized-particular individuals and their descendants received special skills and prerogatives. A dangerous uncle and a random act of violence stood at the origins of a prestigious new line.

Clan myths also draw connections between random acts of violence and the institution of new identities. An enterprising Dutch official collected several dozen of such stories. ${ }^{55}$ Most of them begin with a fight over a domestic animal or some other object of shared desire. A dog defecates inside a hilltop clan house, sparking an altercation between two clan brothers. A man catches a lizard; his brothers eat it; he explodes in rage. A bloody battle ensues, then the siblings disperse, naming features of the landscape as they descend to the coast. In their new homes, the siblings found new clans; eventually their descendants marry. Exploding a sibling set consisting of competing equals, the lethal violence causes a migration that sets up differences and provides a basis for exchange.

Village histories show how a particular relation to the foreign underwrites the connection between violence and origins. In 1912, Lieutenant W. K. H. Feuilletau de Bruyn arrived on Biak with a company of soldiers. ${ }^{56}$ While his mission was ostensibly to capture the murderer of an Ambonese teacher-who had strayed into a drunk warrior's path-he used the occasion to pacify the island's north coast. Using "local methods," his troops snuck up to clan houses and took their occupants as hostages. They refused to release the men, women and children until they turned over any warriors in their midst. Soon the company was traveling with a string of prisoners, bound together by wire tied around their necks. The lieutenant scarcely cuts an endearing figure in his report on the mission. But in the stories Biaks tell about the operation, they remember him with admiration, as well as awe. "Dekna," as they call him, may have been jahat, but he opened a new era on the island. Ostensibly out to bring an end to heathen justice, Feuilletau de Bruyn, through these stories, has become a warrior himself.

Stories about Dekna are taken as relating a particularly treasured beginning in Biak: the dawn of Christian light in heathen darkness. It was in the 1910s that most Biak villages began the long history of mission schooling that accounts for the islanders' dominance in many arenas of provincial life. But while the flag raising undeniably could be emplotted in the colonial story of Biak's march to modernity, this story does not capture the full range of readings evoked by the act. For one thing, it cannot account for the ways that Biaks represent the military and bureaucracy as foreign: dangerous, yet available for present-day warriors who want to advance in the eyes of their peers. For another, it cannot explain the persistence of a view of national liberation as an abrupt and total transformation. As a fourth and final example makes clear, the violence and value of the foreign stands not only at the beginning of Biak identities, but also at the end.

55 See de Bruyn, "Jaarverslagen 1947 en 1948."

56 See W. K. H. Feuilletau de Bruyn, "Militaire Memorie der Schouten-eilanden," August 31, 1916, Nienhuis Collectie van de Department van Bevolkszaken Hollandia Rapportenarchief, Nummer Toegang 10-25, Stuk 183, Algemeene Rijksarchief, The Hague. See also Schouten en Padaido-eilanden, vol. 21 of Mededeelingen Encyclopaedisch Bureau (Batavia: Javaasche Boekhandel, 1920). 


\section{Danilyn Rutherford}

Punctuated by a series of startling encounters and violent incidents, the myth of Manarmakeri, literally "the Itchy Old Man," lays out the origin of the foreign.57 The story begins with the hero's discovery and loss of Koreri, which means "We Change Our Skin," a utopian state of unending life and pleasure also glossed by Biaks as "Kan do mob oser," "We eat in one place." Disappointed by his inability to return to the cave where he witnessed Koreri, Manarmakeri develops a skin disease that covers his body with itching, oozing sores. The hero becomes a migrating outcast, subjected to all manner of abuse. In the key incident in the story, he regains access to Koreri from the Morning Star, whom he surprises when the spirit is stealing the old man's palm wine. But the old man must take a detour in order to return to Koreri: Manarmakeri first gains the power to impregnate a woman magically and make her his wife. The woman turns out to be the local chief's daughter, whose newborn son outrages the villagers when he identifies the old stranger as his father. Rejected again, when his affines flee the misbegotten family, the old man sets about performing miracles. He conjures up a magnificent feast and a modern steamship; he turns himself into a beautiful youth and his skin into treasure by jumping into a raging fire. But even these deeds cannot win him the Biaks' acceptance. Disappointed, Manarmakeri travels west. But someday, he will return and "open" Koreri. This final union with the foreign will end the world as Biaks know it. There will be no more striving, suffering, and death.

Over the course of a long history of contact with outsiders, Biaks periodically gathered to welcome Manarmakeri. ${ }^{58} \mathrm{~A}$ leader would arise, claiming to be in contact with the ancestor; followers would abandon their gardens and gather to sing, dance, and drink palm wine, sure that Koreri soon would begin. While not every incident ended violently, the followers consistently posited a reversal in existing structures of power. ${ }^{59}$ Closing the gap between Biak and the Land of the Foreigners, the return of Manarmakeri would spell the end of a social order based on the pursuit of exogenous sources of value and power. Where New Order narratives repressed all reference to endings, for Biaks, this eschatological moment was-and remains-a focus of longing and hope.

I am certainly not the first to suggest Koreri's importance to the interpretation of Papuan nationalism on Biak; prominent Papuan nationalists have done the same.60 Scholars who take millenarianism as a stage in the "evolution of revolution" have made much of the mixture of political and religious rhetoric that Koreri prophets used to describe their quest. ${ }^{61}$ The reading I would like to offer of the flag raising avoids the

\footnotetext{
57 See Rutherford, Raiding the Land of the Foreigners, pp. 378-461.

58 See F.C. Kamma, Koreri: Messianic Movements in the Biak-Numfor Culture Area (The Hague: Martinus Nijhoff; 1972).

59 An early prophet instructed the faithful to stop traveling to Tidore; instead they should deliver their tribute to him. Ibid., p. 106. Later prophets undermined the authority of the missionaries by claiming that the Bible was really an abridged edition of Biak myth.

60 See for example Nonie Sharp with Markus Wonggor Kaisiëpo, The Morning Star in Papua Barat (North Carlton, Australia: Arena, 1994).

61 See Peter Worsley, The Trumpet Shall Sound (New York: Schocken Books, 1968), p. 48. "The urban and adjoining areas of long settlement, then, on the whole found other forms of political expression than millenarianism, and the casual labourers, peri-urban workers and small entrepreneurs had begun to develop orthodox political, economic and social organizations before World War II." Peter Lawrence also discusses the relationship between cargoism and "modern" political activism. See Peter Lawrence, Road
} 
teleological premises of such an approach. I will not venture into debates on the millennial origins of the modern notions of progress that infuse classic accounts of millenarianism. ${ }^{62}$ How the "phenomenon" looks depends on the perspective of the observer: the events of 1939-42 on Biak, called a "cargo cult" by some, coincided with a multitude of similar reactions that later found a place in the annals of the Indonesian revolutionary war. ${ }^{63}$ If Koreri is central to my analysis, it is not because millenarianism is a precursor to "real" revolution. Using Koreri as a lens, we catch a glimpse of the eschatological limit that all revolutions in some sense evoke.

The Morning Star flag, which refers explicitly to an episode from the myth of Manarmakeri, first flew in 1942, during an uprising which coincided with the Japanese invasion and the collapse of Dutch colonial rule. ${ }^{64}$ While my information on the 1998 flag raising is admittedly incomplete-and I certainly would not want to downplay the significant differences between the two historical moments-what I heard in Biak and read in reports on the previous incident suggest certain parallels. The most striking, of course, is the timing: the fall of a seemingly permanent regime. In both cases, the rupture came at the end of a period of expansion in the scope and reach of the state. $A$ second parallel pertains to the participants. Planned by individuals with recent experience outside the island, the World War II uprising drew people from all parts of Biak, with the prophets and their close relatives forming the core of the movement. It was launched by Angganeta Menufandu, a traditional singer and healer, who had worked on the mainland as a coolie. After her arrest, the movement was carried forward by a group of young warriors who had just been released from jail. Educated in the Philippines and employed at the governor's office in Jayapura, Philip Karma had only recently returned to Biak when the flag raising occurred. Surrounded by relatives from his North Biak village, Karma attracted followers ranging from the teenagers who loiter near the Biak City terminal to villagers who made special trips to town to see the long-forbidden flag. As was the case in the earlier incident, some of the curious ended up staying on.

A third parallel can be drawn in the activities undertaken during the flag raising. At the camps set up by Angganeta and her successors, followers drank palm wine and danced in a circle, singing songs composed by their leaders. The performance genre was wor, a non-diatonic genre of singing once central to Biak ceremonies and feasts. ${ }^{65}$ The leaders were helped by "peace women," as they called male and female dancers who had been possessed by the foreign and the dead. Christian imagery was central to the

Belong Cargo (Prospect Heights, IL.: Waveland Press, 1971), pp. 256-273. See also Michael Adas, Prophets of Rebellion: Millenarian Protest Movements against the European Colonial Order (Cambridge: Cambridge University Press, 1987).

${ }^{62}$ For a discussion of these debates, see Malcolm Bull, "On Making Ends Meet" in Apocalypse Theory and the Ends of the World, ed. M. Bull (Oxford: Oxford University Press, 1995), pp. 1-17. See also Benedict Anderson, "Further Adventures of Charisma" in Language and Power: Exploring Political Cultures in Indonesia (Ithaca: Cornell University Press, 1990), pp. 90-93.

63 I make this argument in Rutherford, Raiding the Land of the Foreigners, pp. 485-87.

${ }^{64}$ See Osborne, Indonesia's Secret War, p. 51; see also Kamma, Koreri, and Rutherford, Raiding the Land of the Foreigners, pp. 525-565.

65 See Philip Yampolsky and Danilyn Rutherford, eds., Music of Biak, Irian Jaya: Wor, Church Songs, Yospan, Vol. 10, The Music of Indonesia (Washington: Smithsonian Institute/Folkways Records, 1996 compact disc). 
movement; people and places received biblical names. Last summer, the demonstrators spent their days dancing around the water tower and singing Biak and Indonesian songs. While they performed a contemporary genre, in fitting with the youth of many of the participants, the allusion to Koreri and Biak feasting was clear. Every hour, the entire group dropped to their knees and prayed, led by Philip Karma. It is said that the leader even "baptized" the territory where the demonstrators exercised control. Although I heard nothing about speaking in foreign tongues, people did describe the reading of incomprehensible foreign documents: "proclamations" in English and Dutch.

A fourth parallel concerns the stress the followers placed on foreign recognition. Elsewhere I have compared the state-sponsored revival of wor, the above-mentioned song genre, in the 1990 s to a similar revival sponsored by the mission in the $1930 \mathrm{~s} .{ }^{66} \mathrm{In}$ the uprisings that followed, Biaks responded to the sense that outsiders had found something unexpected in their identities. In prison, the young warriors who took over from Angganeta heard rumors of Japanese promises to honor native political parties. Upon their release, they drafted an elaborate charter for New Guinea's future, which became the basis of the movement's subsequent phase. Like the warriors, Karma and his followers acted in the belief that powerful outsiders had recognized their plight. Above I mentioned the letter from the US Representatives, which circulated widely on Biak. ${ }^{67}$ Much was made of a rumor that the protesters had appeared on CNN. As was the case in Koreri, this evidence of foreign attention brought to mind not only the gaze of outsiders, but also their impending presence. When one friend left for the port to meet a passenger liner during the demonstration, his neighbor asked him, in great excitement, "Has the foreigners' ship arrived?"

A fifth parallel relates to the interplay between order and violence as the demonstration progressed. Angganeta, who called herself "the Peace Woman," gained authority from her ability to provide convincing signs of direct contact with Manarmakeri. Her successors gained prominence by claiming to represent the prophetess, the "Queen" whose troops they vowed to command. In two sites on Biak, they drilled divisions of the "New America" army. Teachers and evangelists were submitted to beatings; a policeman and a Japanese commander were killed. As the Japanese gradually assumed control of northwestern New Guinea, the new administration tried different strategies to quell the movement, including recruiting the followers of one leader to attack those of another. Finally, in October 1943, the Japanese navy opened fire on a huge crowd of unarmed believers. The bullets failed to turn to water, and hundreds of people were killed. But that was not the end of the violence. A blood bath resulted when grieving families turned on the clans who had led their loved ones to their death. Over a much shorter period, the 1998 demonstration evolved towards a violent confrontation. Early in the protest, Karma formed a security force of sorts. The protesters set up roadblocks around the water tower manned by boys wearing armbands that read "Security Guard -- OPM." The demonstrators began to stockpile weapons after hearing rumors that the military was planning to attack the crowd. When news of the shootings reached young sympathizers in outlying neighborhoods, they took revenge by burning down migrants' shops.

\footnotetext{
66 See Rutherford, "Of Birds and Gifts: The Revival of Tradition on an Indonesian Frontier," p. 601.

${ }^{67}$ Karma reputedly had other documents in his possession, including statements from the 1950s and 1960s relating to the Act of Free Choice.
} 
Perhaps the strongest indication that the narrative of Koreri was evoked in the flag raising comes from the comments I heard after its failure. Friends spoke of Karma's movement in the same tone that they used to discuss Angganeta and the warriors' the goal was valid, but the timing was wrong. "We can't chase it," sighed the wife of a high-ranking official. "God will give it to us in his time." Just as believers found posthoc justifications for Angganeta's failure, they found reasons for the flag raising's tragic ending. Maybe God was on Karma's side, I was told, and the shootings were meant to happen so that more people would hear about the cause. The same friend reported how, after the incident, a Sino-Indonesian woman had had a vision of angels dancing with the demonstrators around the flag. Although Biaks envision independence in a variety of ways, many assume that divine intervention will somehow be involved in its delivery. In 1998, as in the early 1940s, the violence that will end the status quo is imagined as entailing a congress with foreigners and a triumph of prayers-if not machetes-over guns.

\section{Conclusion: The Future of the End?}

From the perspective of day-to-day life, the return of Manarmakeri must remain unpredictable. Prophets who dare to venture a forecast run a risk. Many Biaks still honor the memory of Angganeta, who turned her body into a receiver of messages from Manarmakeri. They have nothing but contempt for her successors, who actively directed the movement in her name. The comments I collected on Philip Karma seemed to range between these alternatives. Some spoke scornfully of this "big foreigner" who led others to ruin because he wanted to "make it"-i.e. independence--all by himself. But others who implied that the movement was divinely ordained spoke of the "light" in Karma's eyes.

The ambivalence Biaks expressed in their judgement of both movements' leaders reflects something of their ambivalent views on violence. If one must in some sense be dangerous to engage in exchange, when Biaks manifest their potency by inflicting bodily harm, the effect on social relations can be devastating. When the plan to involve West Biak villagers failed, the commander assigned Biak soldiers to lead the attack on the demonstrators; it may be years before the families involved mend the rift. ${ }^{68}$ Still if Biaks generally assert that violence should be less than "real," their actions often suggest that it must refer to something more than rhetorical. The massacres that followed the collapse of Koreri in 1943 suggest how easily it is to slip across the line.

One way of grappling with the "not wholly peaceful" nature of episodes like the flag raising is to create taxonomies. F. C. Kamma, the Dutch missionary who wrote a well-known study of Koreri, spoke of a conflict between followers who truly longed for redemption and those who turned this longing to earthly ends. But the comments of those who still remember the movement suggest a more complicated dynamic. Angganeta's movement sought to collapse limits, but it also recreated them, through the brutal suppression of those who failed to follow Manarmakeri's supposed commands. In normal times, Biak justice has no room for an inexplicable death; one's

${ }^{68}$ The soldiers were commanded by a Biak officer, who is ironically, Philip Karma's sister's husband's father. 
misfortune is always attributable to another's misdeed. The leaders of Koreri violently suppressed this principle of retribution by calling for an end to all feuds. The vengeful relatives of the victims of the Japanese attack forcefully reinstated Biak law. Koreri's violence was not simply the outcome of repression or the schemes of "secondary leaders." 69 The violent suppression of order elicited its violent reintroduction, in a dynamic that culminated in the movement's horrific denouement.

There is little doubt that the war-time movement, like the flag raising, involved what Walter Benjamin calls in the beginning of "Critique of Violence" "law-making" and "law-preserving" uses of force. But we get a better sense of what was at stake in Koreri by considering the end of Benjamin's essay, where he tells us that violence can be either mythical or divine. Mythical violence resembles that of the Biak warrior: violence not as a means, but as a manifestation, as seen in a man, "impelled by anger ... to the most visible outbursts of a violence that is not related as a means to a preconceived end."70 Without a pre-existing program to guide it, lawmaking, as "power-making," must take place in such a manifestation, a sign of the "existence of the gods." 71 Like the blow of a warrior or enraged clan brother, mythical violence institutes an order and produces authority by parading as an "alien" force beyond conscious, "local" control. Divine violence looks more like the moment evoked in Koreri: the utter annihilation of order through an imagined collapse of the distance that divides the transcendent sources of value and power from everyday life. I say "evoked" advisedly, because even Angganeta could not convey a pure vision of eschatological destruction. ${ }^{72}$ For Benjamin, divine violence is an element of all revolutions, but it is never possible to pinpoint the order-destroying moment. ${ }^{73}$ How can one depict the elusive instant when one regime ends and another begins?

But it may be that the power of Koreri lies precisely in the elusiveness of its object. At moments when Biaks are drawn to see themselves from the perspective of outsiders, they evoke this figure of a millennial limit. Koreri portrays the submission to other orders, if fully realized, as spelling the end, not of a worldview, but of the world. On Biak, the dream of Papuan independence has proven remarkably resilient in the face of decades of repression. This is in good part due to the groundedness of Koreri's messianic logic in the practices of everyday life. By valorizing the "foreignness" of government slogans and schemes, Biaks satisfied the demands of New Order hegemony without accepting a New Order sense of self. But one should not assume that Papuan nationalism is immune from the logic of Koreri, which destabilizes any

69 See Michael Barkun, "Introduction: Understanding Millennialism" in Millennialism and Violence, ed. M. Barkun (London and Portland: Cass, 1996), p. 7; Adas, Prophets of Rebellion, pp. 122-137.

70 See Benjamin, "Critique of Violence," p. 294.

71 Ibid., p. 295.

72 See Eric S. Rabkin, "Introduction: Why Destroy the World?" in The End of the World, ed. E. S. Rabkin, Martin H. Greenberg and Joseph D. Olander (Carbondale and Edwardsville: S. Illinois University Press, 1983), pp. vii-xv. Rabkin points out in a study of science fiction, "there are virtually no tales of the end of the world in which all of creation ends." Ibid., p. ix. If millenarianism is a particular mode of narration, as Kermode suggests, then, as is the case with all narratives, the "conclusion" in some sense always eludes one's grasp. See Frank Kermode, The Sense of an Ending (Oxford: Oxford University Press, 1967).

73 "The expiatory power of violence is not visible to men." See Benjamin, "Critique of Violence," p. 300. 
identity defined by its place in a homogeneous order of nations. To dance around the flag is to dance with angels; it brings one into an unsustainable proximity with God.

While its roots extend deep into the colonial past, the Biak I have described in this paper is a product of the New Order. I have no way of telling what the post-Suharto era will bring to the islanders or any of the many other people who suffered under the former regime. Nonetheless, I will leave you with two thoughts to keep in mind while contemplating the future of Biak eschatology. The first is borrowed from a Biak friend who borrowed it from Kamma's book on Koreri. ${ }^{74}$ The second is stolen from the title of an essay by Frank Kermode. 75 "The hope in people's heart may never die," but there is nothing so interminable as "waiting for the end."

74 See Koreri.

75 See Bull, "Waiting for the End" in Apocalpyse Theory and the Ends of the World. 
